\title{
Characterization and Evaluation of Copper and Nickel Biosorption on Acidic Algae Sargassum Filipendula
}

\author{
Sirlei Jaiana Kleinübing, ${ }^{\mathrm{a},}$, Rodrigo Silveira Vieira ${ }^{\mathrm{a}}$, Marisa Masumi Beppu ${ }^{\mathrm{a}}$, \\ Eric Guibal', Meuris Gurgel Carlos da Silva ${ }^{\mathrm{a}}$ \\ ${ }^{a}$ School of Chemical Engineering, State University of Campinas - UNICAMP, \\ CP 6066, CEP 13081-970, Campinas, SP, Brazil \\ ${ }^{\mathrm{b}}$ Ecole de Mines d'Alès, Laboratoire Gènie de l'Environnemental Industriel, \\ 6 avenue de Clavières, F-30319 Alès Cedex, France
}

Received: September 28, 2010; Revised: November 22, 2010

\begin{abstract}
The marine algae Sargassum filipendula was collected from São Paulo seashore (Brazil) and submitted to treatment with acid. The biosorption mechanisms of $\mathrm{Cu}^{2+}$ and $\mathrm{Ni}^{2+}$ ions onto acidic algae Sargassum filipendula were examined using various analytical techniques: Fourier-transform infrared (FT-IR) spectroscopy, scanning electron microscopy (SEM), energy dispersive X-ray spectroscopy (EDX) and potentiometric titration $\left(\mathrm{pH}_{\mathrm{ZPC}}\right)$.

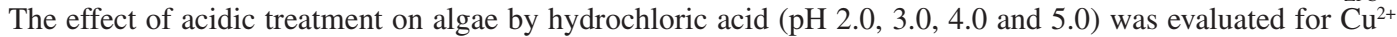
and $\mathrm{Ni}^{2+}$ adsorption. Alginate was extracted from raw algae and the two types of acids present in the biomass ( $\beta$-D-mannuronic (M) and $\alpha$-L-guluronic $(\mathrm{G})$ acid) were characterized by ${ }^{13} \mathrm{C}$ NMR. The $\mathrm{M} / \mathrm{G}$ ratio was found to be 0.50 . According to the $\mathrm{pH}_{\mathrm{ZPC}}$ analysis, at a $\mathrm{pH}$ higher than 5.5 the acidified algae surface presents a negative charge. The FT-IR analyses showed that the main chemical groups involved in the biosorption were carboxylic, alcoholic, sulfonate and amino groups.
\end{abstract}

Keywords: ${ }^{13} \mathrm{C} N M R, F T-I R, M E V / E D X$, alginate, acid treatment

\section{Introduction}

Environmental biotechnology studies have been conducted using alternative materials in order to eliminate heavy metal ions from industrial effluents. Biosorption is a cost effective process that uses inactive biosorbents for decontamination of pollutants, such as heavy metal ions ${ }^{1}$. This process consists in using materials of biological origin, more specifically living or dead microorganisms, to accumulate solute on the surface of the sorbent ${ }^{2}$. Many different kinds of biomass can effectively uptake heavy metals (algae, moss, fungi, bacteria, chitosan and zeolite $)^{2-11}$, but recent research has shown that marine algae are very effective ${ }^{8,12}$ for metal binding.

Seaweed cells have a large superficial area with sites that are able to provide fast and reversible bonding with cations ${ }^{13}$. Sargassum $\mathrm{sp}$. is a widespread and common kind of marine brown algae that has been used for metal recovery, due to the high content of polysaccharides in the cell wall, which are responsible for the high sorption capacity ${ }^{14}$.

This material presents a high organic leaching when used for metal waste treatment. The consequences of the organic leaching can be many and would hinder its industries applications. This can lead to a secondary pollution and also to a decrease in the adsorption performance in water and wastewater treatment ${ }^{14}$. Therefore, it is important to modify the material before its application in biosorption processes. This modification can be done by using acid, base, calcium, or aldehyde ${ }^{14-16}$.

Chen and Yang ${ }^{14}$, studied the surface modification by formaldehyde or glutaraldehydes can result in a significant reduction of organic leaching in cationic biosorption and the biosorption capacity is enhanced due to the modifications and the biosorption kinetics is not affected.
There are several important functional groups in marine algae, such as carboxyl, sulfonic, and amino, which interact with metal ions through different mechanisms, including ion exchange, surface complex formation, micro precipitation, chelation, and coordination ${ }^{17}$.

Raize et al. ${ }^{18}$, using XPS analysis showed that cadmium cations bind to chemical groups possessing oxygen and carbon (carboxyl groups in the alginic acid), nitrogen (amino/amido groups in the peptidoglycans and proteins), and sulfur (sulfonate, thiol in the sulfate polysaccharides and amino acids).

The carboxylic groups are the most abundant acidic functional group and the adsorption capacity of algae is directly related to the presence of these sites in alginate. Alginic acid occurs in all brown algae and corresponds to $45 \%$ of the dry weight, corresponding to $2.25 \mathrm{mmol}$ of carboxyl groups/g of biomass ${ }^{19}$. It is located in the intracellular matrix as a gel containing $\mathrm{Na}^{+}, \mathrm{Ca}^{2+}, \mathrm{Mg}^{2+}, \mathrm{Sr}^{2+}$, and $\mathrm{Ba}^{2+}$ ions ${ }^{20}$. Its main function is believed to be skeletal, giving both strength and flexibility to the algal tissue.

Mannuronic and guluronic acid residues have carboxylic and hydroxyl functional groups that take part in metal binding to alginate ${ }^{18,21-23}$ studied the Sargassum metal $\left(\mathrm{Cd}^{2+}, \mathrm{Ni}^{2+}\right.$ and $\left.\mathrm{Pb}^{2+}\right)$ binding capacities, before and after partial extraction of sulfate polysaccharides (fucoidan) and alginic acid. After extraction, the metal binding capacities decreased by 25,55 , and $75 \%$ for lead, cadmium, and nickel, respectively.

These carboxylic groups can be found in a linear $(1 \rightarrow 4)$-linkedcopolymer of $\beta$-D-mannuronic (M) and $\alpha$-L-guluronic $(\mathrm{G})$ acids. These two acids can be arranged in homopolymeric (MM) and (GG) or heteropolymeric (MG) sequences (blocks) ${ }^{24}$. 
Both the polymer conformation ( $\mathrm{M}$ and $\mathrm{G}$ in the alginate matrix) and the respective proportion of these groups may change with the a) kind of algae; b) the part of the plant where the polysaccharide is extracted; and c) the age or stage in algae growth.

Information about the sequential structure of alginates was obtained early by Haug et al. ${ }^{24}$, and Haug and Smidsrod ${ }^{25}$. They concluded that alginate is a true block copolymer composed of homopolymeric regions of $\mathrm{M}$ and $\mathrm{G}$. They found marked differences among the $\mathrm{M} / \mathrm{G}$ ratios of alginates from different brown algae.

Variation in the affinity of some divalent metals to alginates with different $\mathrm{M} / \mathrm{G}$ ratios was demonstrated early on by Haug et al. ${ }^{24}$, and Haug and Smidsrod ${ }^{25}$. He showed that the affinity of alginates for divalent cations such as $\mathrm{Pb}^{2+}, \mathrm{Cu}^{2+}, \mathrm{Cd}^{2+}, \mathrm{Zn}^{2+}, \mathrm{Ca}^{2+}$, etc. increased with the guluronic acid content. The selectivity coefficients for the ion-exchange reaction between sodium and divalent metals were determined for two alginates ${ }^{25}$ and confirmed the higher affinity of guluronic acid rich alginates for divalent metals.

Brown algae are an abundant source for alginate extraction and this biopolymer is commercially available ${ }^{23}$. Commercial alginates are produced mainly from Laminaria hyperborea, Macrocystis pyrifera, Laminaria digitata, Ascophyllum nodosum, Laminaria japonica, Eclonia maxima, Lessonia nigrescens, Durvillea Antarctica, and Sargassum $\mathrm{sp}^{26}$.

The quality of the alginate extracted from Sargassum species found along the Brazilian coast is inferior and cannot be compared with the quality of the alginate extracted from species of Ascophyllum, Laminaria and Macrocustis ${ }^{27}$. However, the authors point to the possibility that the alginate extracted from Sargassum species found in the Brazilian southwest region may be enough to supply part of the domestic market demand.

A complete chemical characterization of brown algae substrate is necessary to emphasize the advantages of biosorption in relation to the conventional technique of ion-exchange using resins and other materials ${ }^{1}$. This work presents the characterization of Sargassum filipendula algae by solid state ${ }^{13} \mathrm{C}$ NMR nuclear magnetic resonance spectroscopy, in order to determine the $\mathrm{M} / \mathrm{G}$ ratio in the alginate extracted from algae matrix. This $\mathrm{M} / \mathrm{G}$ ratio is important to choose a biosorbent for heavy metal treatment. This study also investigated the influence of acid treatment on algae for copper and nickel adsorption. Techniques such as FT-IR spectroscopy, scanning electron microscopy (SEM) with energy dispersive $\mathrm{X}$-ray spectroscopy (EDX) and $\mathrm{pH}_{\mathrm{ZPC}}$ analysis were used to characterize the biomass, in its raw form, after acidic treatment and metal $\mathrm{Cu}^{2+}, \mathrm{Ni}^{2+}$ binding.

\section{Methods}

\subsection{Sargassum filipendula marine algae}

The Sargassum filipendula marine algae was collected in São Paulo seashore (São Sebastião, Brazil) by the Biology Institute of São Paulo University (CebiMar). The samples were washed and rinsed in distilled water and stored at $-20{ }^{\circ} \mathrm{C}$. Algae samples were dried at $60{ }^{\circ} \mathrm{C}$ overnight and stored in a dry cabinet. The biomass was ground and sieved and fractions measuring from 0.71 to $1.0 \mathrm{~mm}$ were collected for further experiments.

\subsection{Extraction of alginate from marine algae}

The method described by Percival and McDowell ${ }^{28}$ was used for the alginate extraction. The dry algae was soaked in formaldehyde for 24 hours at $60^{\circ} \mathrm{C}$, washed with water and dropped into $\mathrm{HCl}$ solution $\left(0.2 \mathrm{~mol} . \mathrm{L}^{-1}\right)$ for 24 hours. After this time the samples were washed again in distilled water before extraction in $2 \%$ solution of sodium carbonate. In the presence of an excess of $\mathrm{Na}_{2} \mathrm{CO}_{3}$, the alginic acid is converted to a sodium alginate causing polymer dissolution ${ }^{29}$.
Alginate extraction was carried out at $60{ }^{\circ} \mathrm{C}$ by soaking for 3 hours. The samples were centrifuged and the supernatants were labeled as crude extracts. The alginate samples were then obtained from the crude extract by precipitation with ethanol. The precipitate was washed twice with acetone and freeze-dried.

\subsubsection{Solid state MAS ${ }^{13} \mathrm{C}$ NMR nuclear magnetic resonance spectroscopy}

After the alginate extraction procedure the presence of the two types of acids (i.e. guluronic acid (G) and mannuronic acid (M)), were determined using Solid state ${ }^{13} \mathrm{C}$ NMR Nuclear Magnetic Resonance spectroscopy, recorded with a Bruker Avance DRX 500 spectrometer (Bruker, Karlsruhe, Germany).

Solid state NMR of alginate samples (MAS ${ }^{13} \mathrm{C}$ NMR) is a technique that brings the advantage that sodium alginate powder can be examined directly, without need of partial hydrolysis. Normally this partial hydrolysis is used to decrease viscosity of high-molecularweight alginate solutions prior to recording their proton NMR spectra. This step that can induce precipitation of a portion of alginate may significantly distort the experimental results ${ }^{30}$.

\section{3. $\mathrm{pH}_{Z P C}$ analyses}

The procedure described by Davranche et al., ${ }^{31}$ was used to determine the $\mathrm{pH}$ of zero point charge of Sargassum filipendula algae. It was determined according to the surface complexation model, as described by Stumm ${ }^{32}$. Two algae solutions were prepared by immersing $5 \mathrm{~g}$ of algae samples in $100 \mathrm{~mL}$ of $\mathrm{CH}_{3} \mathrm{COONH}_{4}$ $\left(0.1 \mathrm{~mol} . \mathrm{L}^{-1}\right)$ as the supporting electrolyte. Both solutions were titrated with $\mathrm{CH}_{3} \mathrm{COOH}\left(0.3 \mathrm{~mol} . \mathrm{L}^{-1}\right)$ and $\mathrm{NH}_{4} \mathrm{OH}\left(0.25 \mathrm{~mol} . \mathrm{L}^{-1}\right)$.

The titrations were carried out over a wide range of $\mathrm{pH}$. The total surface charge, $\mathrm{Q}$, was calculated as a function of $\mathrm{pH}$ by Equation 1.

$$
\mathrm{Q}=\frac{\mathrm{C}_{\mathrm{A}}-\mathrm{C}_{\mathrm{B}}+\left[\mathrm{OH}^{-}\right]-\left[\mathrm{H}^{+}\right]}{\mathrm{W}_{\mathrm{s}}}
$$

$\mathrm{C}_{\mathrm{A}}$ and $\mathrm{C}_{\mathrm{B}}$ are the acid and base concentrations (mol.L $\mathrm{L}^{-1}$ ), respectively, $\left[\mathrm{H}^{+}\right]$and $\left[\mathrm{OH}^{-}\right]$are the equilibrium concentrations of these ions $\left(\mathrm{mol}_{\mathrm{L}} \mathrm{L}^{-1}\right)$, and $\mathrm{W}_{\mathrm{s}}$ is the solid concentration (g.L $\mathrm{L}^{-1}$ ).

The $\mathrm{pH}_{\mathrm{ZPC}}$ of the solid concentration can be estimated by drawing a curve of the total surface charge as function of $\mathrm{pH}$. The $\mathrm{pH}_{\mathrm{ZPC}}$ is the $\mathrm{pH}$ value where the curve crosses the $\mathrm{x}$-axis $(\mathrm{Q}=0)$.

\section{4. $\mathrm{Cu}^{2+}$ and $\mathrm{Ni}^{2+}$ speciation}

Diagrams of $\mathrm{Cu}^{2+}$ and $\mathrm{Ni}^{2+}$ species distribution as $\mathrm{pH}$ functions were simulated using HYDRA (Hydrochemical EquilibriumConstant Database) software ${ }^{33}$. These diagrams were made for metal at equilibrium concentration $\left(4 \mathrm{mmol} . \mathrm{L}^{-1}\right)$ that corresponded to the maximum copper and nickel adsorption.

\subsection{Acid treatment of Sargassum filipendula marine algae and copper and nickel bioadsorption}

A significantly high amount of organic leaching has been observed in the treatment and recovery of heavy metals by raw biosorbents, with a consequent elevation of $\mathrm{pH}$. The $\mathrm{pH}$ elevation can cause a) metal precipitation; b) metal complexation by soluble ligands released from the algae, which may reduce the metal binding ability of biosorbents.

In this study, biomass particles were pre-treated with hydrochloric acid ( $\mathrm{pH}$ 2.0, 3.0, 4.0 and 5.0) and $\mathrm{pH}$ was continuously adjusted, maintaining it close to the required values, until stabilization was achieved.

Algae samples, $0.5 \mathrm{~g}$ of raw or acid samples, were loaded with $100 \mathrm{~mL}$ of copper and nickel ions $\left(250 \mathrm{mg} . \mathrm{L}^{-1}\right), \mathrm{pH} 4.5$. The 
solubility of metal ions, under selected experimental conditions, was systematically checked. The suspensions were kept in a rotary shaker at $175 \mathrm{rpm}$ for 6 hours. The heavy metal ions concentration was measured by inductive coupled plasma-emission spectroscopy (ICP-ES).

\subsection{Fourier transforms infrared spectroscopy (FT-IR)}

FT-IR spectroscopy was used to confirm the presence of the functional groups in samples of Sargassum filipendula and to observe the chemical modification after heavy metal adsorption in raw and acidified algae. Infrared spectra were recorded in the $4000-600 \mathrm{~cm}^{-1}$ region using a Thermo Nicolet instrument, model IR-200. The ATR (attenuated total reflection) device allows getting information about the surface.

\section{7. $S E M / E D X$}

The surface morphology of algae was observed using scanning electron microscope (SEM). After drying, the samples (0.71 to $1.0 \mathrm{~mm}$ ) were covered with a thin layer of gold $(10 \mathrm{~nm})$ using a sputter coater (SCD 0050 - Baltec, Liechenstein) and observed using the JEOL JXA-840 ${ }^{\mathrm{A}}$ scanning electron microscope $(20 \mathrm{kV})$ under vacuum of $1.33 \times 10^{-6} \mathrm{mBar}$ (Jeol, Japan). To determine the chemical composition, Energy dispersive X-ray spectroscopy was performed on algae after metal adsorption and acidic treatment. The samples were prepared as for SEM analyses. The objective of this analysis was qualitative, not quantitative.

\section{Results and Discussion}

\subsection{Alginate extraction and characterization (Solid state $M A S{ }^{13}$ C NMR spectroscopy)}

To characterize the relation $\mathrm{M} / \mathrm{G}$ in alginate matrix, this material was initially extracted from algae. The complex spectral pattern can be represented as a sum of individual symmetric signals corresponding to the $\mathrm{C}(2)-\mathrm{C}(5)$ atoms of both uronic residues ${ }^{34}$, enough to estimate the $\mathrm{M} / \mathrm{G}$ ratio with high accuracy ${ }^{30}$, assuming that the stronger, downfield peak is due to the main constituent, the $\alpha$-L-guluronic acid.

The alginate composition can be determined by using the relation of total area: G-4+G-2+G-3+G-5 (guluronic) for M-4+M-2+M-3+M-5 (mannuronic) (Table 1). The $\mathrm{M} / \mathrm{G}$ ratio was found to be 0.50 .

This relation is a very important parameter to choose an alga for application in heavy metal treatments. It varies according to the extraction methodology and the location from which the algae was collected $^{29}$, as well as according to seasonal and growth conditions ${ }^{35}$. The comparison of the M/G ratio from other Sargassum species is given in Table 2.

Table 2 indicates different M/G rations for S. fluitans: 0.19 ${ }^{[29]}$, $0.52^{[37]}$ and $1.18^{[19]}$. For $S$. filipendula: $0.19^{[38]}$ and 0.50 (This study). These differences can be attributed due to changes in geographical locations and season of algae collect.

It has been reported ${ }^{40}$ that most Sargassum alginates have M:G ratios ranging from 0.8 to 1.5 . This will be discussed in more detail below and, as indicated in preceding sections of this review, low M:G ratios (i.e. < 1.0) are indicative of higher $\mathrm{G}$ content and are, therefore, deemed highly advantageous for the implementation of the biosorption process. This reflects the established selectivity for divalent cations of the guluronic block sections, in accordance with the "egg-box" model".

Many studies show high affinity of the Sargassum species, from different locations, in the removal of copper and nickel heavy metals: for copper values of 0.93 and $0.89 \mathrm{mmol} . \mathrm{g}^{-1}$ for S. vulgare and S. filipendula, respectively ${ }^{41}$, of $0.99^{[42]}$ and $1.062^{[43]}$ for Sargassum sp., had been found. For nickel, values of $0.75,0.41$ and 0.09 mmol. $\mathrm{g}^{-1}$ for S. fluitans, S. natans, and $S$. vulgare respectively ${ }^{44}$ and 0.61 for Sargassum sp. ${ }^{16}$; and 0.32 for $S$. wightii ${ }^{45}$. There are few published papers that compare brown algae regarding the presence of mannuronic and guluronic $(\mathrm{M} / \mathrm{G}$ ration) acids with the removal capacity of heavy metals, which makes comparison difficult.

Considering that the main responsible for metal biosorption from brown seaweed species is biopolymer alginate, the determination of relation $\mathrm{M} / \mathrm{G}$ in this biopolymer can be a basic factor in the election of the material for application as biosorbent in the heavy metals biosorption process.

\section{2. $\mathrm{pH}_{\mathrm{ZPC}}$ analysis}

Carboxylic, amino and sulfate groups are the main binding sites in brown algae for metal adsorption. These groups can be ionized when $\mathrm{pH}$ varies. At low $\mathrm{pH}$ values, surface sites are protonated and the surface becomes positively charged, whilst the ionizable groups lose their protons and the surface becomes negatively charged at high $\mathrm{pH}$ values. Figure 1 depicts the charge variation in function of $\mathrm{pH}$ for in nature and acidified ( $\mathrm{pH}$ 5.0) algae. For the in nature algae the $\mathrm{pH}_{\mathrm{ZPC}}$ values were within the range of $\mathrm{pH} 6.0$ and 7.0, and for the acidified algae $(\mathrm{pH} 5.0)$ the $\mathrm{pH}_{\mathrm{ZPC}}$ values were within the range of $\mathrm{pH} 5.5$ and 6.0. This means that at $\mathrm{pH}$ higher than 7.0 and 6.0, algae surface bears negative charges, for in nature and acidified algae, respectively. This difference is decurrently of the composite leaching gifts in the biomass (with consequent increasing of $\mathrm{pH}$ ) before the acid treatment. This explains why the binding of many metals increases with increasing $\mathrm{pH}$.

The $\mathrm{pH}$ dependence of metal biosorption can be explained by the fact that there is a competition among $\mathrm{H}^{+}$with heavy metal ions through a combination of mechanisms: ion exchange and the formation of surface metal complexes ${ }^{14}$. At low $\mathrm{pH}$, this competition is strong, hence the metal uptake is lower. When $\mathrm{pH}$ is increased, the competitive effect becomes less important and more heavy metal ions are removed.

However, the adsorption mechanism is determined not only by the functional groups on the sorbents but also the characteristics of metal solutes. Both metal speciation in the solution and the functional groups on the biosorbents are relevant to metal binding mechanisms ${ }^{1}$.

\section{3. $\mathrm{Cu}^{2+}$ and $\mathrm{Ni}^{2+}$ speciation}

Figure $2 \mathrm{a}$ and $\mathrm{b}$ show the distribution of copper and nickel species as a $\mathrm{pH}$ function for metal at equilibrium concentration of $4 \mathrm{mmol} . \mathrm{L}^{-1}$ for $\mathrm{Cu}^{2+}$ and $\mathrm{Ni}^{2}$, respectively.

It was observed that $\mathrm{Cu}^{2+}$ precipitate occurs above $\mathrm{pH} 5.0$ with formation of $\mathrm{CuO}_{(\mathrm{cr})}$. In the case of $\mathrm{Ni}^{2+}$, precipitation occurs above $\mathrm{pH}>6$ with formation of $\mathrm{Ni}(\mathrm{OH})_{2(\mathrm{c})}$. In order to perform the adsorption study of these metals, it is necessary to keep the $\mathrm{pH}$ below 5.0 for copper ions and about 6.0 for nickel ions.

\subsection{Pre-treatment of Sargassum filipendula marine algae and biosorption of $\mathrm{Ni}^{2+}$ and $\mathrm{Cu}^{2+}$}

Marine algae contain a high amount of organic substances, such as carbohydrates, protein, lipids, and pigments. Some of these compounds may be leached from the biomass and can be released to the aqueous phase during the biosorption operation ${ }^{46,47}$. It is common to observe that after biosorption water changes to a yellowish or green color.

The effect of acidic treatment on algae by hydrochloric acid $(\mathrm{pH} 2.0,3.0,4.0$ and 5.0) was evaluated for copper and nickel 
Table 1. Peak intensity obtained by analysis of MAS ${ }^{13} \mathrm{C}$ resonances attributed to residues of $\alpha$-L-guluronic (G) and $\beta$-D-mannuronic acid (M) in sodium alginate of Sargassum filipendula.

\begin{tabular}{|c|c|c|c|c|c|c|c|c|c|}
\hline & \multicolumn{4}{|c|}{ M peaks } & \multicolumn{4}{|c|}{ G peaks } & \multirow[t]{2}{*}{$\mathrm{M} / \mathrm{G}$ ratio } \\
\hline & M-5 & M-4 & M-3 & M-2 & G-5 & G-4 & G-3 & G-2 & \\
\hline Peak (ppm) & 81.3 & 83.0 & 79.4 & 75.8 & 68.8 & 83.3 & 71.0 & 66.0 & \multirow{2}{*}{0.50} \\
\hline Intensity & 2.9 & 3.3 & 3.0 & 5.1 & 12.5 & 3.4 & 7.7 & 5.1 & \\
\hline
\end{tabular}

Table 2. M/G ratio of alginate materials extracted from different Sargassum species.

\begin{tabular}{lccc}
\hline Sargassum species & Origin & M/G & Reference \\
\hline S. vulgare & Brazil (Northern) & 1.27 & 36 \\
\hline S. fluitans & Cuba & 0.52 & 37 \\
S. oligocystum & Australia & 0.62 & \\
\hline S. multicum & England & 0.31 & 38 \\
S. thunbergii & Korea & 0.53 & \\
S. oligocystum & Australia & 0.77 & \\
S. polycystum & Unknown origin & 0.21 & \\
S. filipendula & Unknown origin & 0.19 & \\
S. dentifolium & Egypt & 0.52 & 39 \\
S. asperifolium & & 0.69 & \\
S. latifolium & & 0.82 & \\
\hline S. fluitans & Florida & 1.18 & 19 \\
S. fluitans & Cuba & 0.19 & 29 \\
S. siliquosum & & 0.72 & \\
S. muticum & England & 0.31 & \\
\hline S. filipendula & Brazil (Southeast) & 0.50 & This study \\
\hline
\end{tabular}

adsorption (Figure $3 \mathrm{a}$ and $\mathrm{b}$ ). A slight variation in copper and nickel removal was observed when compared to raw algae, indicating a decrease of $\mathrm{pH}$ from 5.0 to 4.0. For a $\mathrm{pH}$ variation from 3.0 to 2.0, an average decrease of $30 \%$ was observed for both copper and nickel.

The highest effect in adsorption properties at low $\mathrm{pHs}$ can be explained by the chemical modification in the active sites, resulting from the treatment with acid. A weight loss of 27 and $26 \%$ was observed at $\mathrm{pH} 2.0$ and 3.0 and 23 and $22 \%$ at $\mathrm{pH} 5.0$ and 4.0, respectively.

It is interesting to observe that the decrease in sorption efficiency is not correlated to weight loss. Almost the same weight loss occurred at $\mathrm{pH} 5$ and 2, while the sorption capacity remained unchanged at $\mathrm{pH} 5$, whereas it decreased by $40-50 \%$ at $\mathrm{pH} 2$ and 3 . This probably means that this weight loss is not responsible foe the decrease in sorption capacity. This may be explained by the $\mathrm{pH}$ effect on the interaction of metal ions with binding groups (both on the sorbent and or the compounds leached).

At lower $\mathrm{pH}$, the concentration of $\mathrm{H}^{+}$ions is higher, leading to a lower sorption of metals ions. These ions may compete with metal ions for the cell wall ligands.

For copper ions, the $\mathrm{pH}$ should be lower than 5.0 to avoid precipitation of these species, as shown on copper speciation diagrams (Figure 2a). In this way, an acid treatment at $\mathrm{pH} 5.0$ can allow the treated biomass to be used for metal recovery without significantly affecting biomass adsorption capacity. This fact is especially important when using a large sample amount, where the leaching and $\mathrm{pH}$ increase are both maximized.

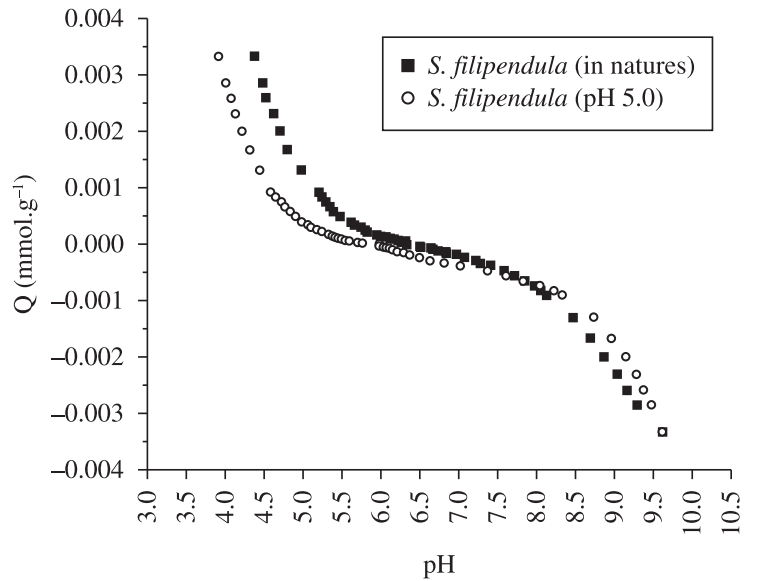

Figure 1. Total surface charge of in nature and acidified (pH 5.0) Sargassum filipendula algae as function of $\mathrm{pH}$.

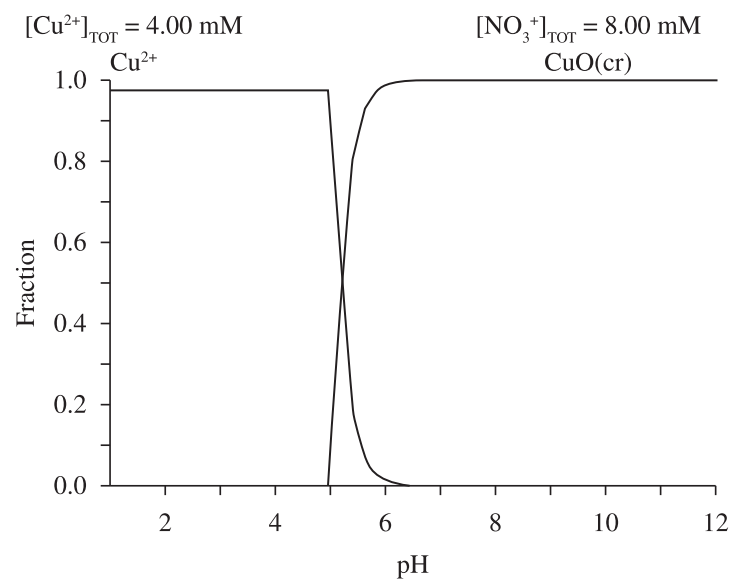

(a)

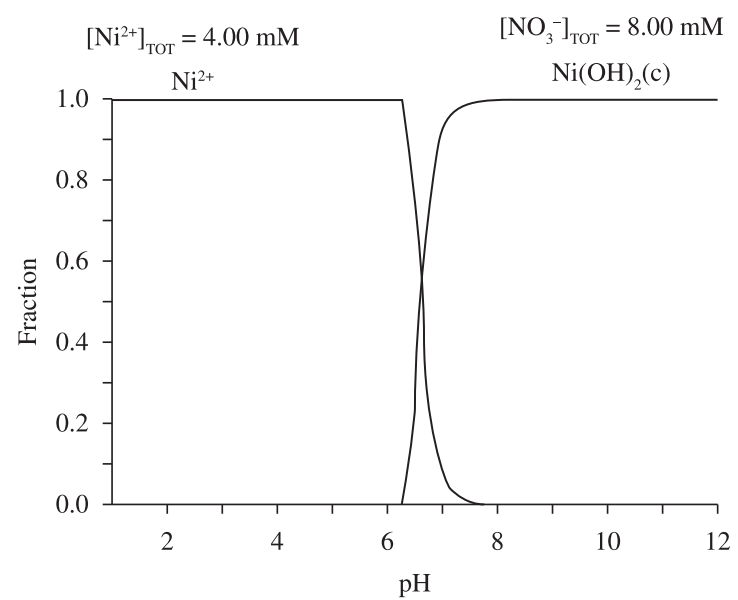

(b)

Figure 2. a) $\mathrm{Cu}^{2+}$; and b) $\mathrm{Ni}^{2+}$ speciation in adsorption as a function $\mathrm{pH}$. 


\subsection{Fourier transform infrared spectroscopy (FT-IR)}

FTIR spectroscopy has been frequently used to detect vibration frequency changes in seaweeds ${ }^{14,16,48-50}$. This technique has been used to evaluate the presence of heavy metals in the biomass algae. The extension of band shifting indicates the degree of interaction of functional groups with metal cations ${ }^{50}$.

In this study, FTIR spectroscopy was used to evaluate the changes in vibration spectra of raw and acidic algae ( $\mathrm{pH} 5.0)$. The same evaluation was performed after copper and nickel loading on raw and acidic algae.

\subsubsection{Identifying the peaks on raw algae}

For raw Sargassum filipendula algae a broad band centered at 3430 and at $3284 \mathrm{~cm}^{-1}$ can be attributed to stretching modes of amino $\left(-\mathrm{NH}_{2}\right)$ and alcohol groups $(-\mathrm{OH})$, respectively. According to Svecova et al. ${ }^{51}$, the presence of amine groups is usually confirmed by the presence of a shoulder around $3265 \mathrm{~cm}^{-1}$, this peak is frequently hidden by vibrations of $-\mathrm{OH}$ groups. The signal at $2928 \mathrm{~cm}^{-1}$ is related to $\mathrm{C}-\mathrm{H}$ stretching modes, and the asymmetric stretching of carboxylate $\mathrm{O}-\mathrm{C}-\mathrm{O}$ vibration at $1640 \mathrm{~cm}^{-1}$. The band at $1411 \mathrm{~cm}^{-1}$ may be due to $\mathrm{C}-\mathrm{OH}$ deformation vibration with contribution of $\mathrm{O}-\mathrm{C}-\mathrm{O}$ symmetric stretching vibration of carboxylate group ${ }^{52}$. The bands at $1530-1560 \mathrm{~cm}^{-1}$ can be assigned to amino groups $(\mathrm{NH}$ stretching $)^{16}$. A band at $1531 \mathrm{~cm}^{-1}$ was found for algae. The bands at about $1235 \mathrm{~cm}^{-1}$ representing $-\mathrm{SO}_{3}$ stretching are mainly present in sulfonic acids of polysaccharides, such as fucoidan ${ }^{49}$. The band at $1022 \mathrm{~cm}^{-1}$ is assigned to the C-O stretching of alcohol groups ${ }^{49}$.

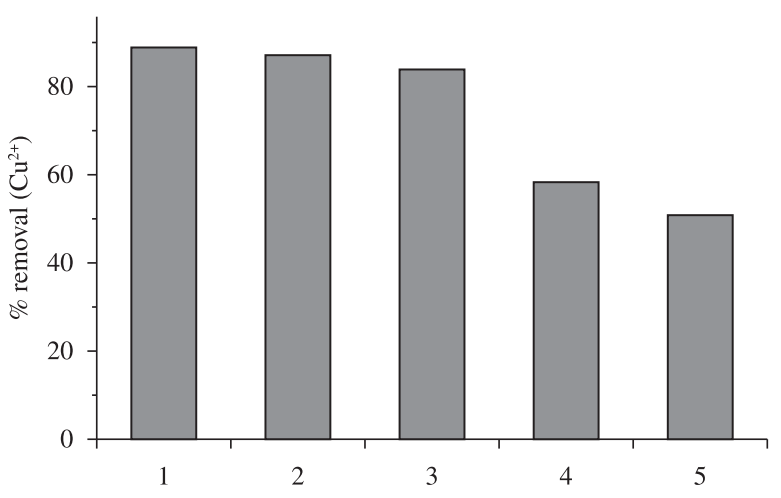

1 (raw algae), 2 ( $\mathrm{pH} 5.0), 3$ ( $\mathrm{pH} 4.0), 4$ ( $\mathrm{pH} 3.0), 5$ ( $\mathrm{pH} \mathrm{2.0),}$

(a)

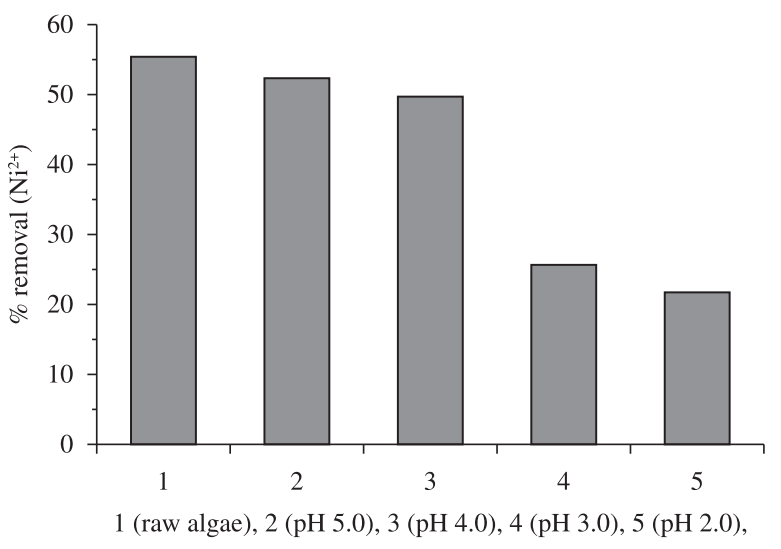

(b)

Figure 3. Comparison of a) $\% \mathrm{Cu}^{2+}$ removal; and b) $\% \mathrm{Ni}^{2+}$ removal of raw and acidified Sargassum filipendula.

\subsubsection{Changes promoted by treatment acid at $\mathrm{pH} 5.0$}

Table 3 shows the changes observed after biomass acidification were: from 1640 to $1612 \mathrm{~cm}^{-1}, 1531$ to $1533 \mathrm{~cm}^{-1}, 1411$ to $1417 \mathrm{~cm}^{-1}$, 1235 to $1250 \mathrm{~cm}^{-1}$ and 1022 to $1039 \mathrm{~cm}^{-1}$. That is, the carboxylic, alcoholic, and sulfonate groups were significantly influenced by the biomass acidification.

In accordance with Sheng et al. ${ }^{49}$, a strong peak at $1640 \mathrm{~cm}^{-1}$ is due to the carboxylate salt COO-M, where $\mathrm{M}$ can be $\mathrm{Na}^{+}, \mathrm{K}^{+}, \mathrm{Ca}^{2+}$, and $\mathrm{Mg}^{2+}$ metals, which are naturally present in marine algae. This band changes to $1612 \mathrm{~cm}^{-1}$ after acid treatment, that is, with acid treatment metal species (M) naturally present in marine algae were replaced by hydrogen ion.

After the treatment with acid, the presence of new peaks was observed in the region of $950-750 \mathrm{~cm}^{-1}$. This region is most discussed in carbohydrates ${ }^{52,53}$. The treatment of algae with $\mathrm{HCl}$ can have caused the lyses of alginate and fucoidan polysaccharide, presents in the algae.

\subsubsection{Changes promoted by $\mathrm{Cu}^{2+}$ and $\mathrm{Ni}^{2+}$ loading in raw and acidified algae}

Table 4 shows that after $\mathrm{Cu}^{2+}$ binding, in raw algae, the asymmetric carboxyl stretching band shifted from 1640 change to $1636 \mathrm{~cm}^{-1}$, and after $\mathrm{Ni}^{2+}$ binding, it shifted to $1632 \mathrm{~cm}^{-1}$. The band attributed to the symmetric stretching of these same groups at $1411 \mathrm{~cm}^{-1}$, changed to $1415 \mathrm{~cm}^{-1}$ for $\mathrm{Cu}^{2+}$ and to $1370 \mathrm{~cm}^{-1}$ for $\mathrm{Ni}^{2+}$.

According with the Table 5, for treated algae, the band at $1612 \mathrm{~cm}^{-1}$ changed to 1635 and $1627 \mathrm{~cm}^{-1}$ after copper and nickel binding, respectively, while the band at $1417 \mathrm{~cm}^{-1}$ moved to 1398 and $1421 \mathrm{~cm}^{-1}$ after copper and nickel binding, respectively.

This shift can be explained by the associations of the carbonyl groups with metal ions ${ }^{49}$. The large variation for copper ions can be attributed to the largest affinity of these species and the algae.

Raize et al., ${ }^{18}$ observed that during the biosorption process the metal ions in solution can also be exchanged with biomass protons. Copper biosorption with $F$. vesiculous was estimated to be $77 \%$ due to ion exchange with $\mathrm{Ca}^{2+}, \mathrm{Mg}^{2+}, \mathrm{Na}^{+}$and $\mathrm{K}^{+}$ions ${ }^{54}$.

Table 3. Changes promoted by treatment acid at $\mathrm{pH} 5.0$

\begin{tabular}{|c|c|}
\hline Raw algae $\mathrm{cm}^{-1}$ & Acidified algae (pH 5.0) $\mathrm{cm}^{-1}$ \\
\hline 2928 & 2950 \\
\hline 1640 & 1612 \\
\hline 1531 & 1533 \\
\hline 1411 & 1417 \\
\hline 1235 & 1250 \\
\hline 1022 & 1039 \\
\hline
\end{tabular}

Table 4. Changes promoted by $\mathrm{Cu}^{2+}$ and $\mathrm{Ni}^{2+}$ loading in raw algae.

\begin{tabular}{ccc}
\hline $\begin{array}{c}\text { Raw algae } \\
\mathrm{cm}^{-1}\end{array}$ & $\begin{array}{c}\text { In nature algae } \\
\text { saturated with } \mathrm{Cu}^{2+} \\
\mathrm{cm}^{-1}\end{array}$ & $\begin{array}{c}\text { In nature algae } \\
\text { saturated with } \mathrm{Ni}^{2+} \\
\mathrm{cm}^{-1}\end{array}$ \\
\hline 2928 & 2943 & 2921 \\
1640 & 1636 & 1632 \\
1531 & - & 1535 \\
1411 & 1415 & 1370 \\
1235 & 1220 & 1213 \\
1022 & 1037 & 1033 \\
\hline
\end{tabular}


Studies using Sargassum stated that cadmium biosorption occurred by the formation of ionic bridges between the metal and two carboxyl groups or a bidentate chelating complex with one carboxyl group ${ }^{19}$.

Regions of the alginate polymer that are rich in " $G$ " residue, provide a multi-dentate environment for complexation, whereas in regions that are rich in mannuronic acid, complexation would be predominantly monodentate and therefore, weaker. In guluronic acid, the ring oxygen and the axial $\mathrm{O}-1$ form a spatially favorable environment with $-\mathrm{COO}$, as opposed to the equatorial $\mathrm{O}-1$ which occurs in mannuronic acid residues ${ }^{1,38}$.

The analysis of spectra obtained before and after copper and nickel binding indicated that the $-\mathrm{NH}$ group was involved in biosorption process. For raw algae, the band at $1531 \mathrm{~cm}^{-1}$ disappears after copper adsorption and moves to $1535 \mathrm{~cm}^{-1}$ after nickel adsorption, while for treated algae the band at $1533 \mathrm{~cm}^{-1}$ changes to $1543 \mathrm{~cm}^{-1}$ after copper adsorption. The changes in intensity of the bands in the $3430 \mathrm{~cm}^{-1}$ region also suggested changes in the amino groups present in the biomass.

The infrared frequency at $1235 \mathrm{~cm}^{-1}$ represents $\mathrm{SO}_{3}$ stretching. For raw algae, Table 4, this band changes to 1220 and $1213 \mathrm{~cm}^{-1}$ in the presence of $\mathrm{Cu}^{2+}$ and $\mathrm{Ni}^{2+}$ respectively. Analyzing Table 5 for the band at $1250 \mathrm{~cm}^{-1}$ (acidic algae), nearly the same frequency was observed for Ni binding $\left(1248 \mathrm{~cm}^{-1}\right)$, while for $\mathrm{Cu}$ binding, it changed to $1226 \mathrm{~cm}^{-1}$. This fact can be explained by copper complexation on fucoidan groups present in the algae, either for raw or acid algae. For nickel ions, after acid treatment, metal complexation was not observed.

Table 5. Changes promoted by $\mathrm{Cu}^{2+}$ and $\mathrm{Ni}^{2+}$ loading in acidified algae.

\begin{tabular}{ccc}
\hline $\begin{array}{c}\text { Acidified algae } \\
(\mathrm{pH} \mathrm{5.0}) \mathrm{cm}^{-1}\end{array}$ & $\begin{array}{c}\text { Acidified algae } \\
\text { saturated with } \mathrm{Cu}^{2+} \\
\mathrm{cm}^{-1}\end{array}$ & $\begin{array}{c}\text { Acidified algae } \\
\text { saturated with } \mathrm{Ni}^{2+} \\
\mathrm{cm}^{-1}\end{array}$ \\
\hline 2950 & 2945 & 2938 \\
1612 & 1635 & 1627 \\
1533 & 1543 & - \\
1417 & 1398 & 1421 \\
1250 & 1226 & 1248 \\
1039 & 1037 & 1036 \\
824 & 822 & 852 \\
740 & 743 & - \\
\hline
\end{tabular}

The band at $1022 \mathrm{~cm}^{-1}$ was assigned to the C-O stretching of hydroxyl groups. In raw algae, this band shifts to 1037 and $1033 \mathrm{~cm}^{-1}$ after $\mathrm{Cu}^{2+}$ and $\mathrm{Ni}^{2+}$ sorption, respectively.

According to Mackie ${ }^{55}$, alginates showed two characteristic bands at 808 and $787 \mathrm{~cm}^{-1}$ in the IR spectra, assigned to mannuronic and guluronic acids, respectively. Here, the band identified at $824 \mathrm{~cm}^{-1}$ (Table 5) moved to $822 \mathrm{~cm}^{-1}$ after $\mathrm{Cu}^{2+}$ binding and to $852 \mathrm{~cm}^{-1}$ in the presence of $\mathrm{Ni}^{2+}$. After $\mathrm{Cu}^{2+}$ sorption the band at $740 \mathrm{~cm}^{-1}$ slightly moved to $743 \mathrm{~cm}^{-1}$.

\subsection{SEM/EDX - Sargassum filipendula}

The morphology of algae surface was analyzed by scanning electron microscopy before and after the acidic treatment and after copper and nickel loading. The presence of diatom shells in the outer algae surface was systematically observed. In diatoms, the cell wall is composed of silica, to which protein and polysaccharide are added. Even after the diatom dies and the organic materials have disappeared, the external structure remains, showing that the siliceous component is indeed to decay of these diatom frustules, they remain intact for long periods of time and constitute some of the best algal fossils ever found ${ }^{56}$. Diatoms outer shells are fixed on algae surface. There was a high variability of these shell quantity, with regions with large amounts and regions where diatoms are not observed, (Figure 4a-e).

Figure 4(b-e) shows the effect of treatment with acid. These changes were probably caused due to strong cross-linking between the $\mathrm{H}^{+}$and negatively charged chemical groups in the cell polymer. In the raw algae are high concentrations of calcium, sodium, magnesium, etc. (Table 6) and these bind to alginic acid monomers. This binding creates a net of cross-linking.

When the Sargassum filipendula samples were exposed to heavy metal solution, the cations replaced some of the cation initially present in the cell wall matrix and created stronger cross-linking ${ }^{18}$.

In order to characterize the chemical composition and the location of the diatom outer shell on algae surface scanning electron microscopy (SEM) with energy dispersive X-ray spectroscopy (EDX) was used, Figures $5 \mathrm{a}$ and $\mathrm{b}$. High silicon amounts were observed in the regions where the diatom outer shells were present, due to the fact that silicate groups are the principal components of these microorganisms.

The Figure 6 and 7, presents scanning electron microscopy (SEM) with energy dispersive X-ray spectroscopy (EDX), when the algae (treated $\mathrm{pH}$ 5.0) it is saturated with the heavy metals copper and nickel, respectively. Again the presence of diatoms is observed and the quantity of metals copper and nickel did not suffer variation in locations with or without the presence of diatoms.

Table 6. Elemental composition of Sargassum filipendula treated in the different pHs.

\begin{tabular}{|c|c|c|c|c|c|c|c|c|c|c|}
\hline \multirow[t]{3}{*}{ Element } & \multicolumn{10}{|c|}{ Composition } \\
\hline & \multicolumn{2}{|c|}{ In nature } & \multicolumn{2}{|c|}{ pH 5.0} & \multicolumn{2}{|c|}{$\mathrm{pH} 4.0$} & \multicolumn{2}{|c|}{$\mathrm{pH} 3.0$} & \multicolumn{2}{|c|}{$\mathrm{pH} 2.0$} \\
\hline & wt. (\%) & at. $(\%)$ & wt. $(\%)$ & at. $(\%)$ & wt. $(\%)$ & at. $(\%)$ & wt. (\%) & at. $(\%)$ & wt. $(\%)$ & at. $(\%)$ \\
\hline $\mathrm{Mg}$ & 1.43 & 13.07 & 1.49 & 17.56 & 0.72 & 10.31 & 0.52 & 8.52 & 0.22 & 5.09 \\
\hline $\mathrm{Na}$ & 1.09 & 10.49 & - & - & - & - & - & - & - & - \\
\hline $\mathrm{Al}$ & 1.58 & 13.02 & 0.61 & 6.49 & 0.89 & 11.44 & 0.63 & 9.19 & 0.21 & 4.38 \\
\hline $\mathrm{Si}$ & 4.11 & 32.56 & 1.71 & 17.49 & 1.93 & 23.73 & 1.57 & 22.15 & 0.61 & 12.29 \\
\hline $\mathrm{Cl}$ & 0.61 & 3.82 & - & - & 0.24 & 2.37 & 0.35 & 3.89 & 1.35 & 21.73 \\
\hline $\mathrm{Fe}$ & 0.85 & 3.37 & 0.34 & 1.75 & 0.58 & 3.57 & 0.38 & 2.69 & - & - \\
\hline $\mathrm{S}$ & - & - & 3.06 & 27.33 & 1.63 & 17.63 & 2.13 & 26.25 & 2.29 & 40.71 \\
\hline K & 2.31 & 13.13 & 0.61 & 4.45 & 0.33 & 2.89 & 0.34 & 3.39 & - & - \\
\hline $\mathrm{Ca}$ & 1.91 & 10.57 & 3.49 & 24.93 & 3.25 & 28.05 & 2.43 & 23.92 & 1.11 & 15.79 \\
\hline Total & 13.88 & 100.00 & 11.31 & 100.00 & 9.57 & 100.00 & 8.35 & 100.00 & 5.79 & 100.00 \\
\hline
\end{tabular}




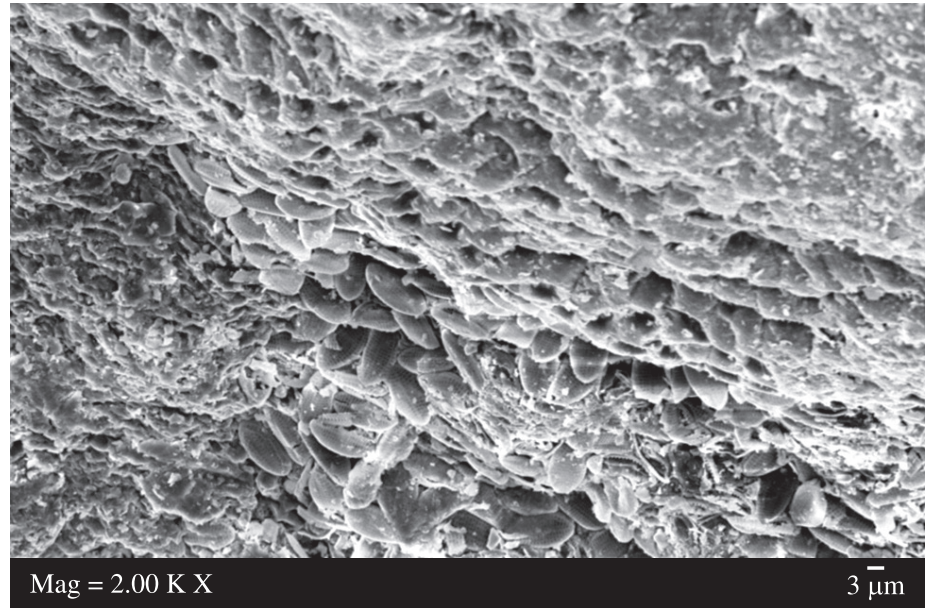

(a)

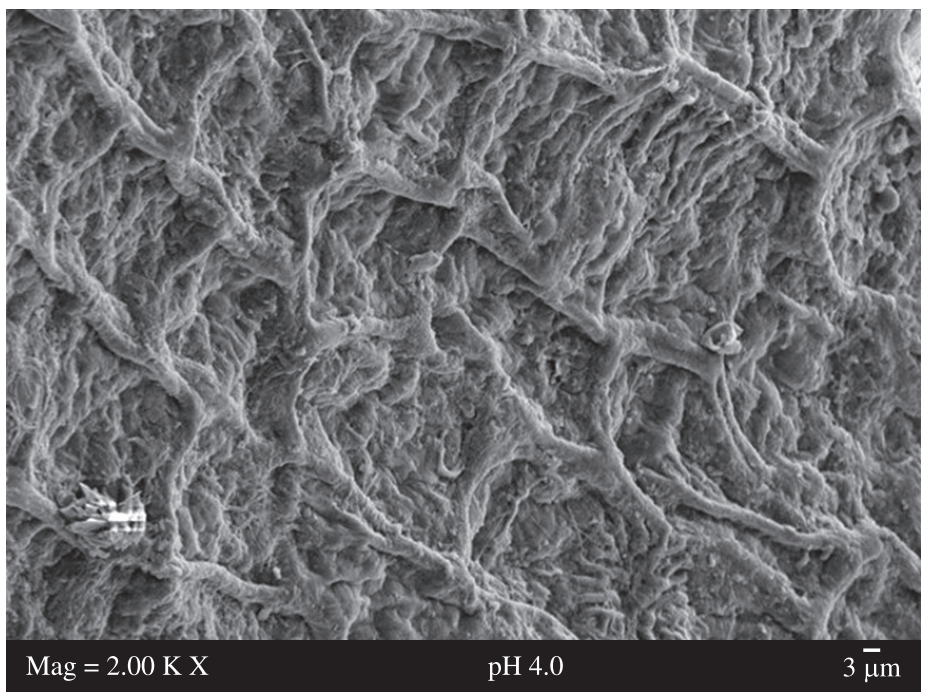

(c)

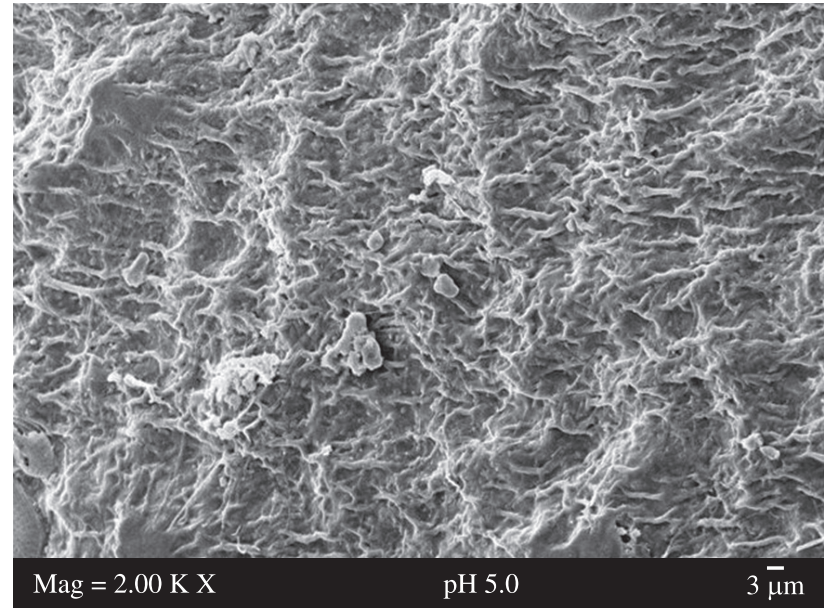

(b)

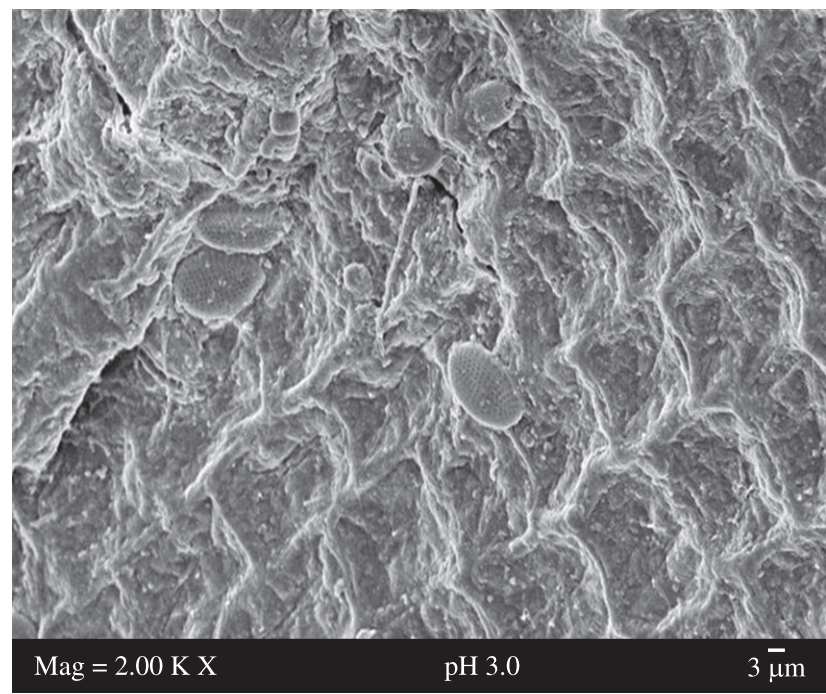

(d)

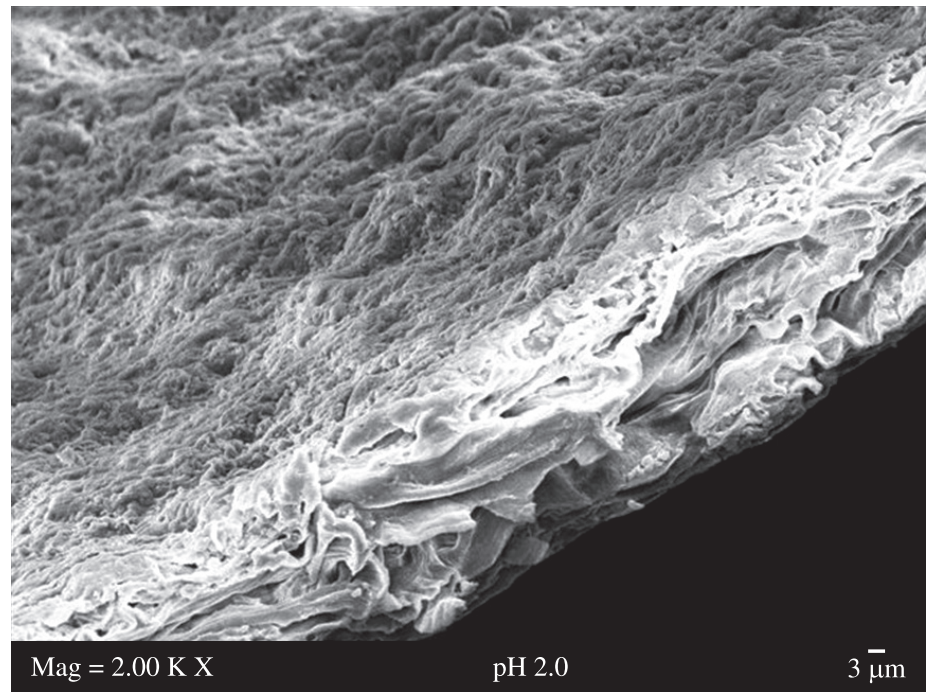

(e)

Figure 4. Scanning electron microscopy (SEM) micrographs (2000× magnification) of a) raw Sargassum filipendula; b) acid treatment Sargassum filipendula $\mathrm{pH} 5.0$; c) acid treatment Sargassum filipendula $\mathrm{pH} 4.0$; d) acid treatment Sargassum filipendula $\mathrm{pH} 3.0$; and e) acid treatment Sargassum filipendula $\mathrm{pH} 2.0$. 


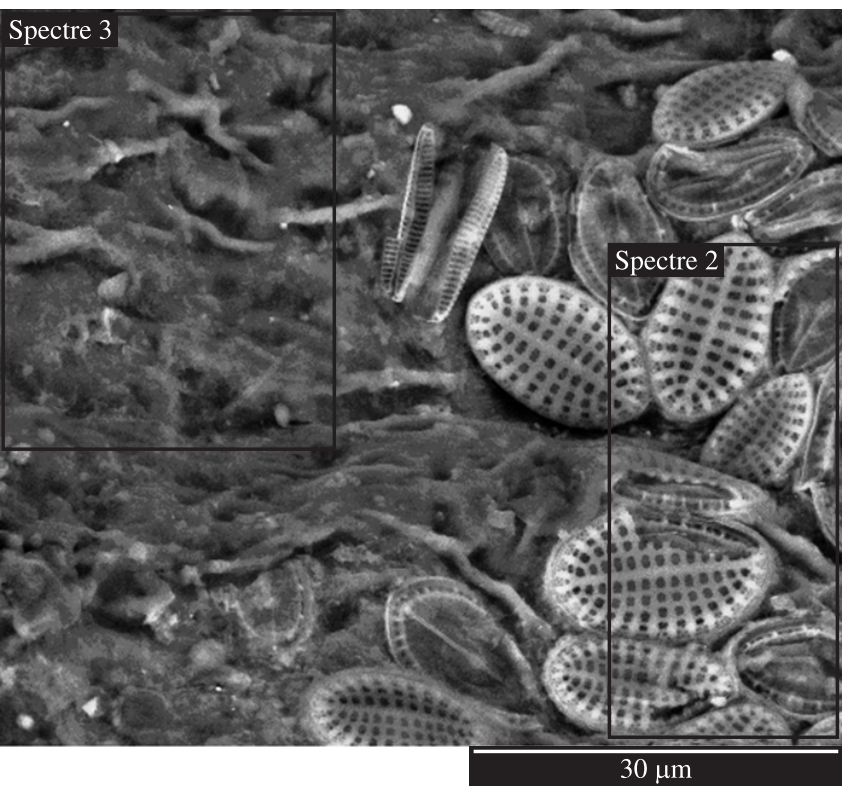

(a)

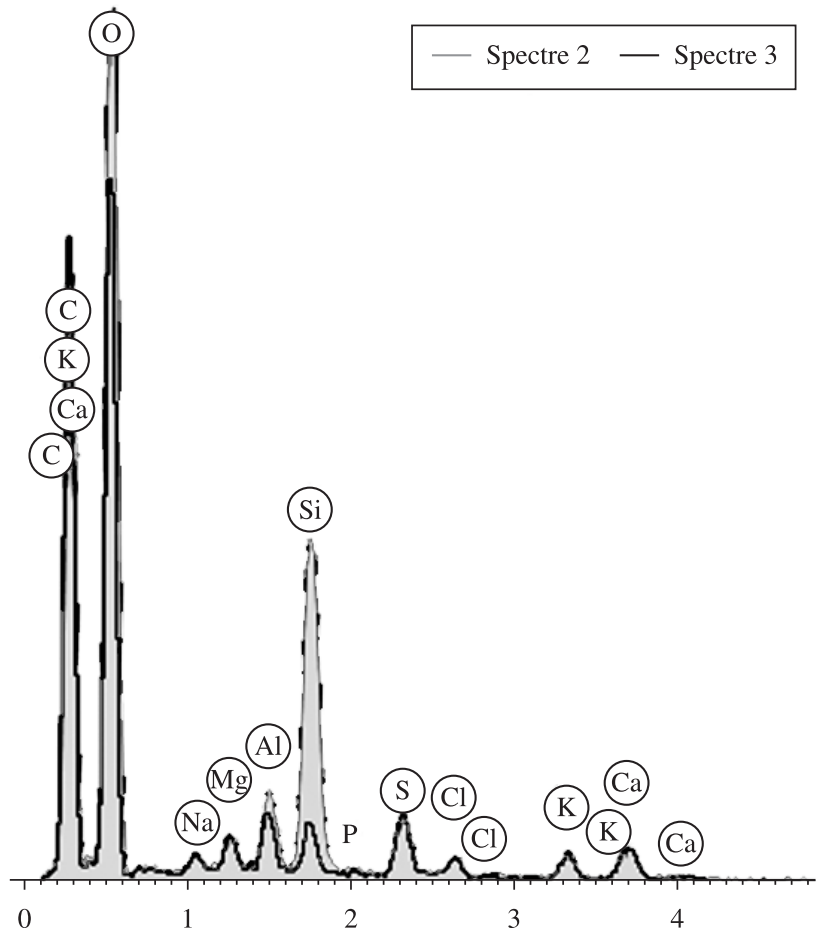

(b)

Figure 5. a) Scanning electron microscopy (SEM) micrographs of Sargassum filipendula treated $\mathrm{pH}$ 5.0; and b) energy dispersive $\mathrm{X}$-ray spectroscopy (EDX) in the regions of spectra 2 and 3 of the SEM.

The cell walls of brown algae generally contain three components: cellulose, the structural support; alginic acid, a polymer of mannuronic and guluronic acids and the corresponding salts of sodium, potassium, magnesium and calcium; and sulfated polysaccharides (fucoidan matrix $)^{56}$

Table 6 shows qualitative results of chemical distribution on algae surface at different $\mathrm{pHs}$. The objective is to compare between the chemical distributions of metals at different $\mathrm{pHs}$ for all samples. The chemical quantification was performed in regions where diatom

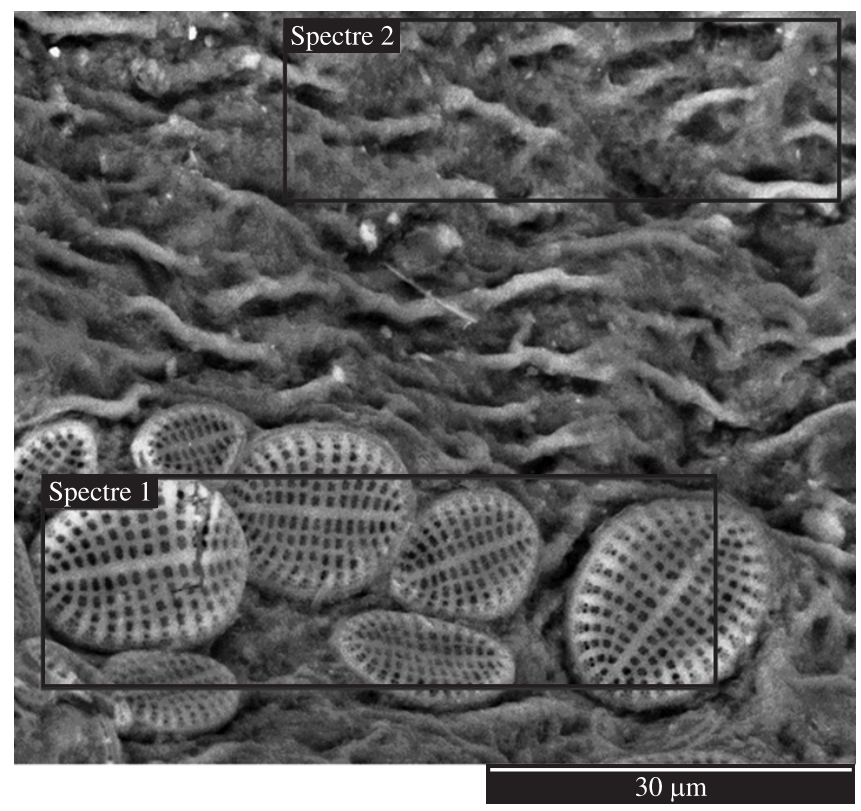

(a)

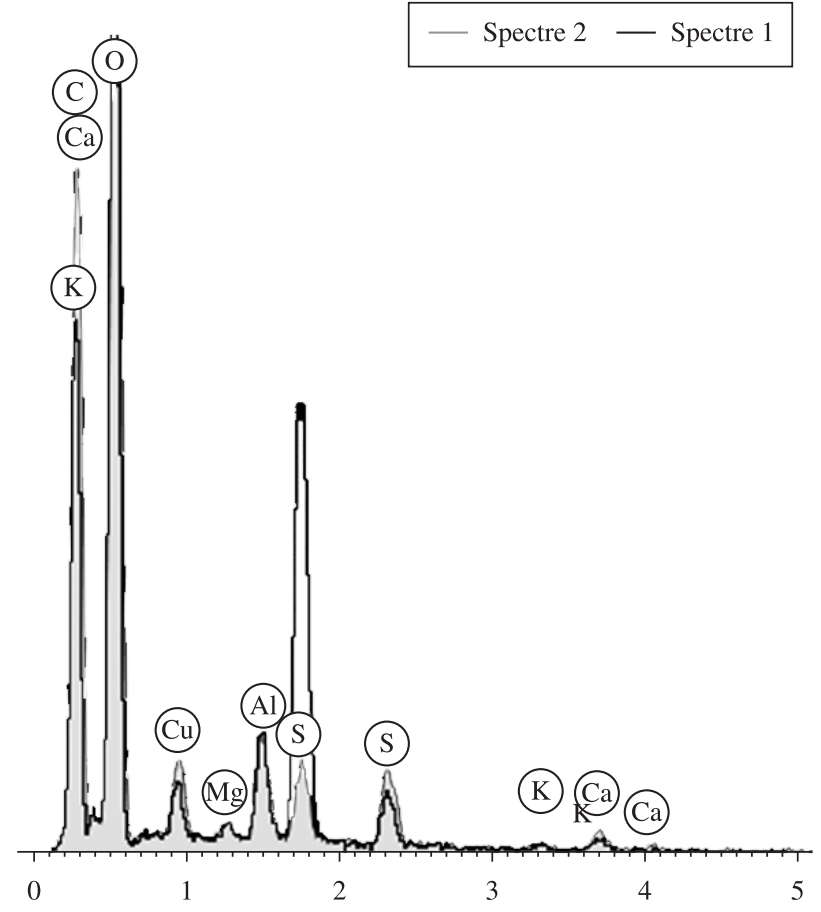

(b)

Figure 6. a) Scanning electron microscopy (SEM) micrographs of Sargassum filipendula treated $\mathrm{pH} 5.0$ saturated with copper; and b) energy dispersive X-ray spectroscopy (EDX) in the regions of spectra 2 and 1 of the SEM.

outer shells were present. It was observed that the acid treatment resulted in the removal of metals such as: $\mathrm{Mg}, \mathrm{Na}, \mathrm{Al}, \mathrm{Si}, \mathrm{Ca}, \mathrm{Fe}$ and $\mathrm{K}$ from algae biomass.

This fact can be related to FTIR results, where the absorption in $1640 \mathrm{~cm}^{-1}$ represents the carboxylate salt COO-M, where M can be the naturally found metals in the algae. The spectra showed alterations after the acid treatment and that was justified by the elimination of these ions. This behavior was more significant in algae acidified in smaller $\mathrm{pH}$ values. 


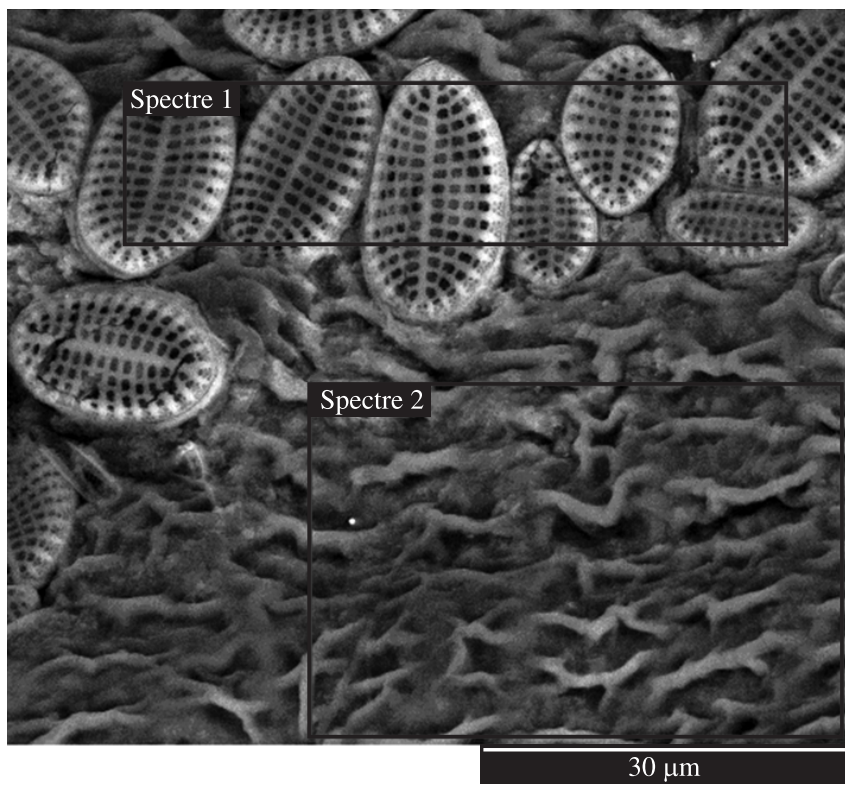

(a)

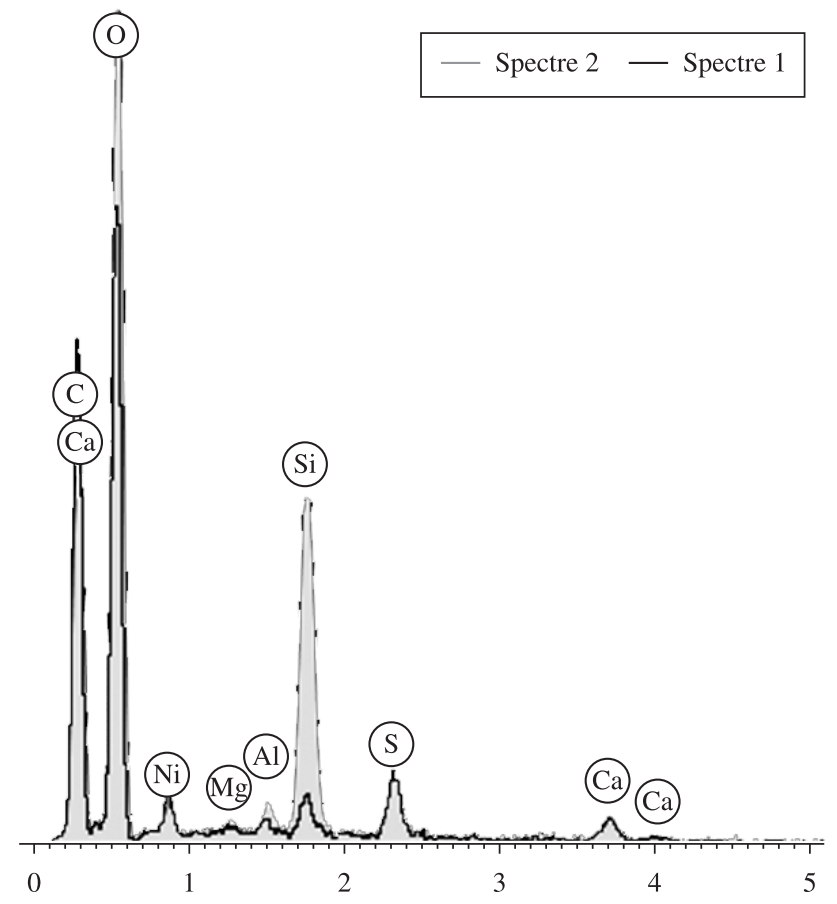

(b)

Figure 7. a) Scanning electron microscopy (SEM) micrographs of Sargassum filipendula treated $\mathrm{pH} 5.0$ saturated with nickel; and b) energy dispersive X-ray spectroscopy (EDX) in the regions of spectra 1 and 2 of the SEM.

\section{Conclusions}

In this work the characterization and evaluation of copper and nickel biosorption was studied on acidic Sargassum filipendula algae. The following conclusions were drawn from the study:

- A controlled acid treatment, at the appropriate $\mathrm{pH}(\mathrm{pH} 5.0)$, prevents the release of organic material during metal sorption and keeps the sorption capacities in the same order of magnitude of raw algal material. Additionally, this pre-treatment allows limiting $\mathrm{pH}$ variation during the sorption process (especially for column application).
- Depending on the algal species used for the extraction of alginic acid its $\mathrm{M} / \mathrm{G}$ ratio presents great variations. In this work the $\mathrm{M} / \mathrm{G}$ ratio found was 0.50 .

- The Fourier transform infrared (FT-IR) analysis demonstrates similar chelating characteristics of copper and nickel coordination to the functional groups in the cell wall of Sargassum filipendula algae. The presence and participation of carboxylic and alcoholic groups in the alginate biopolymer, sulfonate group in the sulfate biopolymer (fucoidan) and amino groups in amino acids are responsible for copper and nickel adsorption.

- The morphology of algae surface was analyzed by scanning electron microscopy and the presence of diatom outer shells was observed, though the presence of this diatom did not have a significant impact in copper and nickel binding.

\section{Acknowledgements}

The authors would like to acknowledge CNPq and FAPESP for the financial support and CEBIMar (USP) for collection and identification of the algal material.

\section{References}

1. Davis TA, Volesky B, Mucci A. A review of the biochemistry of heavy metal biosorption by brown algae. Water Research. 2003; 37:4311-4330.

2. Guibal E. Interactions of metal ions with chitosan-based sorbents: a review. Separation purification Technology. 2004; 38:43-74.

3. Loukidou MX, Zouboulis AI, Karapantsios TD and Matis KA. Equilibrium and kinetic modeling of chromium(VI) biosorption by Aeromonas caviae. Colloids and Surfaces A: Physicochemical and Engineering Aspects. 2004; 242:93-104.

4. Park JM, Park D and Yun Y. Use of dead fungal biomass for the detoxification of hexavalent chromium: screening and kinetics. Process Biochemistry. 2005; 40:2559-2565.

5. Akar T and Tunali S. Biosorption characteristics of Aspergillus flavus biomass for removal of $\mathrm{Pb}$ (II) and $\mathrm{Cu}$ (II) ions from an aqueous solution. Bioresource Technology. 2006; 97:1780-1787.

6. Pavasant $\mathrm{P}$ and Apiratikul R. Sorption isotherm model for binary component sorption of copper, cadmium, and lead ions using dried green macroalga, Caulerpa lentillifera. Chemical Engineering Journal. 2006; 119:135-145

7. Vieira RS. and Beppu MM. Interaction of natural and crosslinked chitosan membranes with $\mathrm{Hg}$ (II) ions. Colloids and Surfaces A: Physicochemical and Engineering Aspects. 2006; 279:196-207.

8. Romera E, González F, Ballester A, Blázquez ML and Muñoz JA. Comparative study of biosorption of heavy metals using different types of algae. Bioresource Technology. 2007; 98:3344-3353.

9. Vieira MGA, Oisiovici RM, Gimenes ML and da Silva MGC. Biosorption of chromium (VI) using a Sargassum sp. packed-bed column. Bioresource Technology. 2008; 9:3094-3099.

10. Mukhopadhyay M. Role of surface properties during biosorption of copper by pretreated Aspergillus niger biomass. Colloids and Surfaces A: Physicochemical and Engineering Aspects. 2008; 329:95-99.

11. Baroni P, Vieira RS, Meneghetti E, Beppu MM and Silva MGC. Evaluation of batch adsorption of chromium ions on natural and crosslinked chitosan membranes. Journal of Hazardous Materials. 2008; 152:1155-1163.

12. Romera E, González F, Ballester A, Blázquez ML and Muñoz JA. Biosorption of heavy metals by Fucus spiralis. Bioresource Technology. 2008; 99:4684-4693.

13. Amorim WB, Hayashi AM, Pimentel PF and da Silva MGC. A Study of Desorption of Hexavalent Chromium. Brazilian Journal of Chemical Engineering. 2003; 20:283-289.

14. Chen JP and Yang L. Chemical Modification of Sargassum sp. for Prevention of Organic Leaching and Enhancement of Uptake during 
Metal Biosorption. Industrial Engineering Chemistry Research. 2005; 44:9931-9942.

15. Kratochvil D, Pimentel P and Volesky B. Removal of Trivalent and Hexavalent Chromium by Seaweed Biosorbent. Environmental Science Technology. 1998; 32:2693-2698.

16. Chen JP and Yang L. Study of a heavy metal biosorption onto raw and chemically modified Sargassum sp. via spectroscopic and modeling analysis. Langmuir. 2006; 22:8906-8914.

17. Vijayaraghavan V and Yun YS. Bacterial biosorbent and biosorption. Biotechnology Advances. 2008; 26:266-291.

18. Raize O, Argaman Y and Yannai S. Mechanisms of biosorption of different heavy metals by brown marine macroalgae. Biotechnology and Bioengineering. 2004; 87:451-458.

19. Fourest $E$ and Volesky B. Alginate properties and heavy metal biosorption by marine algae. Applied Biochemistry and Biotechnology. 1997; 67(1):33-44.

20. Haug, A. Composition and properties of alginates. [Ph.D Thesis]. Trondheim: Norwegian Institute of Technology; 1964.

21. Emmerichs N, Wingender J, Flemming HC and Mayer C. Interaction between alginates and manganese cations: identification of preferred cation binding sites. International Journal of Biological Macromolecules. 2004; 34:73-79.

22. Lamelas C, Avaltroni F, Benedetti M, Wilkinson KJ and Slaveykova VI. Quantifying $\mathrm{Pb}$ and $\mathrm{Cd}$ complexation by alginate and the role of metal binding on macromolecular aggregation. Biomacromolecules. 2005; 6:2756-2764.

23. Lagoa R and Rodrigues JR. Evaluation of dry protonated calcium alginate beads for biosorption applications and studies of lead uptake. Applied Biochemistry and Biotechnology. 2007; 143:115-128.

24. Haug A, Larsen B and Smidsrød O. Uronic acid sequence in alginate from different sources. Carbohydrate Research. 1974; 32:217-225.

25. Haug A and Smidsrod O. The effect of divalent metals on the properties of alginate solutions. II. Comparison of different metal ions. Acta Chemica Scandinavica. 1965; 19:341-351.

26. Smidsrod O and Draget KI. Chemistry and Physical properties of alginates. Carbohydrate in Europe. 1996; 14:6-13.

27. Oliveira-Filho EC and Paula EJ. Potentiality for algin production in the São Paulo (Brazil) littoral region. In: $9^{\text {th }}$ International Seaweed Symposium. 1979; Princeton. p. 479-486.

28. Percival E and McDowell RH. Chemistry and enzymology of marine algal polysaccharides. New York: Academic Press; 1967.

29. Davis TA, Llanes F, Volesky B, Diaz-Pulido G, McCook L and Mucci A. ${ }^{1} \mathrm{H}-\mathrm{NMR}$ Study of Na Alginates Extracted from Sargassum spp. in Relation to Metal Biosorption. Applied Biochemistry and Biotechnology. 2003; 110:75-90.

30. Llanes F, Sauriol F, Morin FG and Perlin AS. An examination of sodium alginate from Sargassum by RMN spectroscopy. Canadian Journal of Chemistry. 1997; 75:585-590.

31. Davranche M, Lacour S, Bordas F and Bollinger JC. An easy determination of the surface chemical properties of simple and natural solids. Journal of Chemical Education. 2003; 80:76-78.

32. Stumm W. Chemistry of the solid-water interface. New York: John Wiley \& Sons; 1992.

33. Puigdomenech I. HYDRA: Hydrochemical Equilibrium-Constant Database Software. Sweden: Royal Institute of Technology; 2004.

34. Grasdalen H, Larsen B and Smidsrod O. ${ }^{13}$ C-N.M.R. Studies of monomeric composition and sequence in alginate. Carbohydrate Research. 1981; 89:179-191.

35. Indergaard M and Skjak-Braek G. Characteristics of alginate from Laminaria digitata cultivated in a high phosphate environment. Hydrobiologia. 1987; 151/152: 541-549.

36. Torres MR, Sousa APA, Silva Filho EAT, Melo DF, Feitosa JPA, de Paula RCM et al. Extraction and physicochemical characterization of
Sargassum vulgare alginate from Brazil. Carbohydrate Research. 2007; 342:2067-2074.

37. Davis TA, Ramirez M, Mucci A and Larsen B. Extraction, isolation and cadmium binding of alginate from Sargassum spp. Journal of Applied Phycology. 2004; 16:275-284.

38. Davis TA, Llanes F, Volesky B and Mucci A. Metal selectivity of Sargassum spp. and their alginates in relation to their $\alpha$-L-Guluronic acid content and conformation. Environmental Science and Technology. 2003; 37:261-267.

39. Larsen B, Salem DMSA, Sallam MAE, Mishrikey MM and Beltagy AI. Characterization of the alginates from algae harvested at the Egyptian Red Sea coast. Carbohydrate Research. 2003; 338:2325-2336.

40. Minghou J, Yujun W, Zuhong X and Yucui G. Sudies on the M:G ratios in alginate. Hydrobiologia. 1984; 116:554-556.

41. Davis TA, Volesky B and Vieira RHSF. Sargassum seaweed as biosorbent for heavy metals. Water Research. 2000; 34:4270-4278.

42. Sheng PX, Ting YP and Chen JP. Biosorption of Heavy Metal Ions ( $\mathrm{Pb}$, $\mathrm{Cu}$, and $\mathrm{Cd}$ ) from Aqueous Solutions by the Marine Alga Sargassum sp. in Single- and Multiple-Metal Systems. Industrial and Engineering Chemistry Research. 2007; 46:2438-2444.

43. Vijayaraghavana K, Teob TT, Balasubramanianc R and Joshi UM. Application of Sargassum biomass to remove heavy metal ions from synthetic multi-metal solutions and urban storm water runoff. Journal of Hazardous Materials. 2009; 164:1019-1023.

44. Holan ZR and Volesky B. Biosorption of lead and nickel by biomass of marine aglae. Biotechnology and Bioengineering. 1994; 43:1001-1009.

45. Vijayaraghavan K, Jegan J, Palanivelu K and Velan M. Biosorption of Copper, Cobalt and Nickel by Marine Green Alga Ulva reticulate in a Packed Column. Chemosphere. 2005; 60:419-426.

46. Figueira MM, Volesky B and Mathieu HJ. Instrumental Analysis Study Of Iron Species Biosorption by Sargassum Biomass. Environmental Science and Technology. 1999; 33:1840-1846.

47. Matheickal JT and Yu Q. Biosorption of lead(II) and copper(II) from aqueous solutions by pre-treated biomass of Australian marine algae. Bioresource Technology. 1999; 69:223-229.

48. Figueira MM, Volesky, Ciminelli, VST and Roddick FA. Biosorption of metals in brown seaweed biomass. Water Research. 2000; 34(1):196-204.

49. Sheng PX, Ting Y-P, Chen JP and Hong L. Sorption of lead, copper, cadmium, zinc, and nickel by marine algal biomass: characterization of biosorptive capacity and investigation of mechanism. Journal Colloid and Interface Science. 2004; 275:131-141.

50. Murphy V, Hughes $\mathrm{H}$ and McLoughlin P. $\mathrm{Cu}$ (II) binding by dried biomass of red, green and brown macroalgae. Water Research. 2007; 41:731-740.

51. Svecova L, Spanelova M, Kubal M and Guibal E. Cadmium, lead and mercury biosorption on waste fungal biomass issued from fermentation industry: I. Equilibrium studies. Separation and Purification Technology. 2006; 52:142-153.

52. Mathlouthi M. and Koenig JL. Vibrational spectra of carbohydrates. Advances in Carbohydrate Chemistry and Biochemistry. 1986; 44:7-66.

53. Tul'chinsky VM, Zurabyan SE and Asankozhoev KA. Study of the infrared spectra of oligosaccharides in the region 1,000-40 $\mathrm{cm}^{-1}$. Carbohydrate Research. 1976; 51:1-8.

54. Cochrane EL, Lua S, Gibb W and Villaescusa I. A comparison of lowcost biosorbents and commercial sorbents for the removal of copper from aqueous media. Journal of Hazardous Materials B. 2006; 137:198-206.

55. Mackie W. Semi-quantitative estimation of the composition of alginates by infra-red spectroscopy. Carbohydrate Research. 1971; 20:413-425.

56. Wang $\mathrm{J}$ and Chen $\mathrm{C}$. Biosorbents for heavy metals removal and their future. Biotechnology Advances. 2009; 27:195-226. 